\title{
Electrochemical hydrogen compression and purification versus competing technologies: Part I. Pros and cons
}

\author{
Maha Rhandi, Marine Trégaro, Florence Druart, Jonathan Deseure, Marian Chatenet* \\ Univ. Grenoble Alpes, Univ. Savoie Mont Blanc, CNRS, Grenoble-INP, LEPMI, 38000 Grenoble, France
}

\section{A R T I C L E I N F O}

\section{Article history:}

Received 20 May 2019

Accepted 15 July 2019

Published 5 May 2020

\section{Keywords:}

Electrochemical hydrogen compression Hydrogen energy

Electrochemical hydrogen purification

Thermdynamics

Efficiency

\begin{abstract}
A B S T R A C T
It is undisputed that hydrogen will play a great role in our future energetic mix, because it enables the storage of renewable electricity (power-to- $\mathrm{H}_{2}$ ) and the reversible conversion into electricity in fuel cell, not to speak of its wide use in the (petro)chemical industry. Whereas in these applications, pure hydrogen is required, today's hydrogen production is still largely based on fossil fuels and can therefore not be considered pure. Therefore, purification of hydrogen is mandatory, at a large scale. In addition, hydrogen being the lightest gas, its volumetric energy content is well-below its competing fuels, unless it is compressed at high pressures (typically $70 \mathrm{MPa}$ ), making compression unavoidable as well. This contribution will detail the means available today for both purification and for compression of hydrogen. It will show that among the available technologies, the electrochemical hydrogen compressor (EHC), which also enables hydrogen purification, has numerous advantages compared to the classical technologies currently used at the industrial scale. EHC has their thermodynamic and operational advantages, but also their ease of use. However, the deployment of EHCs will be viable only if they reach sufficient performances, which implies some specifications that their base materials should stick to. The present contribution will detail these specifications.
\end{abstract}

(C) 2020, Dalian Institute of Chemical Physics, Chinese Academy of Sciences. Published by Elsevier B.V. All rights reserved.

\section{Introduction}

The recent COP21 in Paris demonstrated that most countries are willing to reduce their carbon footprint. One convenient manner to do so is to increase renewable energies (e.g. solar panel and windmills) and to store their excess production into chemicals via a power-to-gas (and in particular power-to-hydrogen) strategy, so that "green" electricity can be produced on demand peaks by converting the gas (hydrogen) into electricity, for instance in fuel cells [1]. Electrolyser systems have a maximum delivery pressure equal to $44.8 \mathrm{MPa}$ with an untreated hydrogen gas purity equal to $99.5 \%$, excluding water vapor. The Impurity is mainly $\mathrm{O}_{2}$ and after deoxidizer, the treated gas purity reaches $99.999 \%$, excluding water vapor [2]. Therefore, purification is not required for water electrolysis except for $\mathrm{O}_{2}$ and water vapor. This is the ideal scenario, and unfortunately, the present hydrogen is still not widely produced using this strategy. Today, more than $95 \%$ of hydrogen is produced from fossils (and in a minor amount from bio-processes) and is therefore not pure [3]. Nevertheless, supplementary hydrogen sources from biomass can contribute to the penetration of renewable energies $([4,5])$, e.g. photobiohydrogen exhibits a positive global warming potential, low acidification potential, relevant social cost of carbon and a low potential production cost [6]. Hence, the biomass processes appear as promising technologies to produce renewable hydrogen [7], but with a large amount of impurities.

This means that widespread usage of hydrogen, e.g. in fuel cell vehicles, stationary power production or for specialty chemistry, requires its efficient purification. If one takes the

\footnotetext{
* Corresponding author. E-mail: Marian.Chatenet@grenoble-inp.fr

DOI: S1872-2067(19)63404-2 | http://www.sciencedirect.com/science/journal/18722067 | Chin. J. Catal., Vol. 41, No. 5, May 2020
} 
case of proton exchange membrane fuel cells (PEMFC) for automotive applications as a benchmark, the level of purity required is as follows: $\mathrm{H}_{2}>99.97 \mathrm{~mol} \%$, hydrocarbons $\mathrm{CO}<0.2$ ppm (mol), $\mathrm{H}_{2} \mathrm{~S}<0.004 \mathrm{ppm}(\mathrm{mol}), \mathrm{NH}_{3}<0.1 \mathrm{ppm}$ (mol), $\mathrm{O}_{2}<5$ ppm (mol), $\mathrm{N}_{2}$ and Ar $<300$ ppm (mol) $([8,9])$. Besides, the volumetric energetic content of hydrogen being small at room pressure, this gas needs to be compressed to fairly high pressures to compete with the usual fuels (e.g. gasoline, natural gas, etc.) [10].

At present, there are many ways to purify and to compress hydrogen. The present contribution will review the most relevant (and widespread) ones, and will particularly focus on their interest for the application of hydrogen-energy (e.g. for fuel cell vehicles). In this application, in order to minimize the hydrogen transportation cost, one option would be to widespread hydrogen production/purification/compression into small units. The present work will particularly address these items and check the pros and cons of each technology for these aspects. It will notably be shown that electrochemical hydrogen compression (EHC) systems enable both purification and compression at reasonable efficiency, and could therefore be the technological solution for such application.

\section{Purification methods}

In order for hydrogen to become a widespread renewable-energy carrier, its purification and compression are unavoidable industrial processes [10]. Currently, these two processes are usually physically separated in, firstly, a purification step to convert impure hydrogen into ultra-pure hydrogen, and then a compression step to make the purified (and low-pressure) hydrogen gas storage sufficiently dense (in terms of gravimetric and volumetric density) to compete with the usual energy vectors (e.g. gasoline, natural gas, etc.). The sections below will detail the different ways to purify and to compress hydrogen gas with present technologies, but also with "future" ones.

\subsection{Different purification methods}

Several approaches enable hydrogen purification in the industry. Hydrogen can be recovered by condensing the impurities (cryogenic process), by adsorbing the impurities (Pressure Swing Adsorption, PSA) or by using perm-selective membranes. Pressure Swing Adsorption (PSA) is the most widely used method for the production of high-purity hydrogen from steam methane reforming: several hundred PSA- $\mathrm{H}_{2}$ process units are currently installed in various parts of the world. It is difficult to compare these three processes, though, because the scale and maturity of these technologies can be strongly different. Therefore, in the following, it is suggested to quote each one from the point of view of their potential users, notably in terms of purity reached (hydrogen purity is based on standard grade classification; the first digit of the grade classification indicates the "number of nines" purity, e.g. N3 or N30 $=99.9 \%$ purity) and of energy-consumption.

Temperature swing adsorption (TSA) is also widely used to purify hydrogen. However, according to Bonjour et al. [11], the main drawbacks of TSA systems is the large energy consumption it requires as well as large masses of adsorbents that are needed. Therefore, TSA does not seem adapted to small units of purification and this method will therefore not be detailed in this work.

\subsubsection{Cryogenic}

Cryogenic processes of hydrogen purification operate at very low temperatures $\left(-253{ }^{\circ} \mathrm{C}[12]\right)$, are therefore highly energy-intensive and incur a high cost; however, the collected hydrogen can be easily stored as a liquid [13], an endeavor in terms of gravimetric and volumetric storage. Although, the purity levels of the extracted hydrogen remain limited with the cryogenic purification (i.e. N20), this method is compatible with low hydrogen contents in the feed, which holds industrial attractiveness: the cryogenic process is typically adapted to large production units, and is therefore not ideally adapted to the wide spreading of smaller units of purification/compression for hydrogen refilling stations for the hydrogen fuel cell vehicles. According to Agrawal et al. [14], membrane technology units (see Section 2.1.3) can be added in the overall process to reduce gas-processing costs in a usual broad range of cryogenic applications (large fraction of impurities).

\subsubsection{Pressure swing adsorption (PSA)}

The state-of-the-art technology of pure hydrogen production in the chemical and petrochemical industries is the PSA process [15]. Although, the PSA process is still being improved, the industrial objectives are to increase both the hydrogen recovery and its purity ( $>$ N40), but also to decrease the adsorbent inventory (capital expense). Mondal et al. [16] have simulated the power consumption in the hydrogen separation process; the main power consumption of the process takes place in the compression units. This power consumption depends on the adsorption pressure and does not take into account the adsorbents used. Nevertheless, the power consumption is also linked to the regeneration step that depends on the bed material and the column volume. In addition, a refrigeration system is required to maintain the adsorption column at ambient temperature $\left(23^{\circ} \mathrm{C}\right)$, the power consumption for the refrigeration being directly linked to the volume of adsorbent. It is observed that a significant energy consumption depends on the inlet gas composition (i.e. low hydrogen concentration required more cycles), which implies that the energy efficiency of the PSA process is affected by the hydrogen purity: to be more specific, the hydrogen purity increases and its recovery decreases if the adsorption pressure and purge-to-feed ratio are increased. Instead, the increase of the production time (low purge-to-feed ratio) and of the production flow rate lead to low hydrogen purity but at excellent recovery of inlet gas [17]. Agueda et al. [18] found that metal organic frameworks (MOFs) were more suitable than zeolites as adsorption materials in the PSA for hydrogen, if longer breakthrough times are targeted. According to Xiao et al. [19] a multi-objective algorithm is required to optimize the PSA process, as the generation of high-purity hydrogen involves shorter feeding time, lower feeding rate and 
lower gas recovery and productivity. Yokozeki et al. [20] have suggested to use ionic liquids in PSA techniques: this separation concept of gaseous mixtures using room-temperature ionic liquids enables far lower energy-consumption than distillation or classical PSA methods, and continuous operation should be easier.

To summarize, PSA is ideal for large industrial scale units; however, the purity levels of the extracted hydrogen scales inversely to the gas recovery and the energetic consumption is high. However, for small units, as those which would be needed to widespread hydrogen refilling stations for the future fleets of hydrogen-powered fuel cell vehicles, PSA appears not ideal and poorly adapted.

\subsubsection{Membrane}

The driving force for hydrogen separation through the membrane is the pressure gradient across the membrane. High gradients are reached by applying a high inlet pressure of gas mixture to the one side of a hermetically-sealed membrane, while a relatively low pressure is fixed on the opposite side: the gradient will initiate the mass-transport through the membrane, leaving behind the impurities (if the membrane material is properly chosen). There are three main types of materials for hydrogen membrane separation: porous membranes, dense membranes and protonic membranes [21].

(1) Porous membranes operate by means of Knudsen diffusion and/or surface diffusion and/or capillary condensation and molecular sieving. Currently, there are numerous porous media for the purpose of hydrogen separation: zeolites, Vycor glass, sintered nickel (metal) and alumina-based or zirconia-based ceramics [22]. Despite this wide choice of porous membrane materials, the porous membrane hydrogen purification process is yet not commercially viable.

(2) In the field of gas separation, polymeric membrane technologies have received extensive attention, but the balance between permeability versus selectivity remains a critical technical problem for a given polymer [23]. Therefore, many research works propose to mix various polymer materials in composite membranes to improve their apparent selectivity and permeability [24]. The performances reached still do not meet the industrial targets, though, and the most advanced technologies for hydrogen separation use dense metal membranes. The most common metallic membrane for hydrogen separation consists of palladium membrane, where the hydrogen flux reaches to $10010^{-3} \mathrm{~mol} \mathrm{~m}^{-2} \mathrm{~s}^{-1}$ for a pressure gradient of $\Delta P=100 \mathrm{kPa}$ and an operating temperature up to $T=450^{\circ} \mathrm{C}$. Many theories have been proposed to elucidate the mechanism behind hydrogen diffusion through a metal lattice [21]. Nevertheless, such metal membranes (including Pd membranes) also bear drawbacks: they can fail due to hydrogen embrittlement and remain expensive (Pd is a scare and expensive element [25]). Some strategies exist to optimize the membranes' lifetime: Pd-coated vanadium membranes are for example known to tolerate the mechanical stress and to reduce the overall cost of the membrane [26]. Despite their larger cost than for polymer ones, metallic membranes remain as the standard selective hydrogen membranes for the industry.
(3) Protonic materials based on mixed proton and electron conductors are intriguing or interesting for dense separation membranes "usage". These membranes are, in theory, $100 \%$ selective because the proton conductivity dominates in these materials, rendering impossible both gas crossover and circulation of other ions. Proton conductivity is ensured by using a ceramic phase, e.g. BZCY $\left(\mathrm{BaZr}_{0.1} \mathrm{Ce}_{0.7} \mathrm{Y}_{0.2} \mathrm{O}_{3-\delta}\right)$. The electro-neutrality in the mixed-conducting membrane is balanced by electron transport in the metal phase (i.e. Ag or Ni). Such composite membranes, based on ceramic proton conductors and metals are often denominated as cermets (cer-met, [27]). Other strategies consist of dual-ceramic composite membranes based on all-ceramic (cer-cer, [28]). Alternative membrane configurations with asymmetrical structure and external short-circuit can ensure the electron transportation by an external-circuit porous metal coating layer [27]. In any case, the proton-conductor ceramic is based on rare earth-doped ceria oxides, which exhibit protonic conductivity at high temperatures between $700{ }^{\circ} \mathrm{C}<T<1000{ }^{\circ} \mathrm{C}$ and low hydrogen permeability.

Membrane processes enable to access to higher values of hydrogen gas purity (N50) than the previous (cryogenic and PSA) methodologies. Nevertheless, the flow rate of a membrane purification process is limited by the membrane permeability, and it is required to employ large surface area of membrane if large fluxes are targeted, which imposes a non-negligible capital cost.

Currently, membrane hydrogen purification units are still limited to small systems, and the hydrogen flux through such membranes is roughly an order of magnitude lower than the target of PSA production.

\subsubsection{Electrochemical hydrogen compressor (EHC)}

Despite its name, EHC, also allows the purification of hydrogen. These devices are based on an assembly comprising anode and cathode gas-diffusion electrodes, and a solid (usually polymer-based) electrolyte situated between the electrodes; the core of the system is usually called membrane electrode assembly (MEA). In an EHC system, electric energy is supplied to the cell to promote the transport of hydrogen (and only hydrogen) from the anodic to the cathodic compartment. To that goal, the operating principle of an electrochemical compressor (EHC) is simply to oxidize impure hydrogen at the positive electrode (anode) and to evolve hydrogen at the negative electrode; in the meantime, the protons produced at the positive electrode selectively migrate to the negative electrode through the proton-conductive membrane (Fig. 1). This process can be summarized by the two electrochemical reactions (1) and (2):

$$
\left\{\begin{array}{c}
\mathrm{H}_{2} \rightarrow 2 \mathrm{H}^{+}+2 \mathrm{e}^{-} \quad(1) \\
\text { hydrogen oxidation reaction, HOR, at the anode } \\
2 \mathrm{H}^{+}+2 \mathrm{e}^{-} \rightarrow \mathrm{H}_{2} \quad(2) \\
\text { hydrogen evolution reaction, HER, at the cathode }
\end{array}\right.
$$

Obtaining pure hydrogen at the outlet requires a minimum electrical work to be supplied to the cell: the theoretical work of purification is given by the Nernst equation [29]. In practice, this theoretical work is not sufficient, and kinetics limitations 


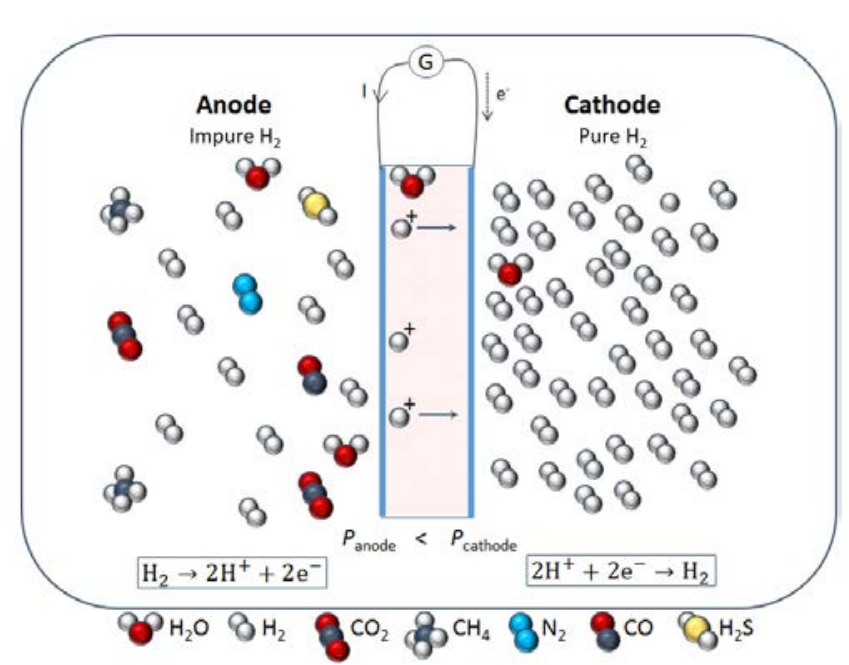

Fig. 1. Operation principle of an electrochemical hydrogen compressor.

should be overcome. They depend on the Ohmic resistance of the cell (both owing to the non-infinite conductivity of the proton-exchange membrane and electrode materials, and the electrical contacts), some charge-transfer limitations (although the HER and HOR are known to be very fast reactions on platinum-based electrodes, their overvoltage values are strictly not zero) and some mass-transport limitations (molecular hydrogen and proton transport to/from the catalytic sites, gas crossover through the membrane). These kinetics limitations increase when the current density increases, which means that the efficiency of an EHC will decrease when its productivity (flux of pure $\mathrm{H}_{2}$ ) increases. In addition, the EHC purification assumes that there are electrocatalysts that enable fast oxidation of impure hydrogen, which is not granted on present anode materials, that usually display low tolerance to some poisons (e.g. $\mathrm{H}_{2} \mathrm{~S}$ and $\mathrm{CO}$ ); these aspects of electrocatalysts will be thoroughly addressed in part II of the contribution "Electrochemical hydrogen compression and purification versus competing technologies: Part II. Challenges in electrocatalysis". At a geometric current density of $j=2 \mathrm{~A} \mathrm{~cm}^{-2}$, EHC reaches the performances of best membrane process previously described, thus EHC is an attractive solution for hydrogen purification. EHC also enable hydrogen compression, which will be dealt with in Section 3.

\subsection{Comparison of purification methods}

As stated above, direct comparison of these different pro- cesses of hydrogen purification is not straightforward (Table 1). Whatever this bias, it was decided to attempt such comparison; it is based on five markers, which have been particularly chosen to benchmark the EHC versus the present industrials hydrogen purification means.

The first marker is the gas recovery. It was set close to 1 for the membrane process and EHC, because in these cases, the purges exhibit a weak percent of feed gas (e.g. near to $1 \%$ or below - they can operate in dead-end mode), whereas it is higher for the PSA and cryogenic processes (their purge-to-feed ratio is usually higher than $20 \%$ ), resulting in lower gas recovery marker value. The second marker is the operating temperature convenience: the choice was made to set this value of quotation of the operating temperature to 1 if the operating temperature is between room temperature and $200{ }^{\circ} \mathrm{C}$ material durability and sealing system are very convenient, to 0.5 for temperature comprised between $200{ }^{\circ} \mathrm{C}<T<500{ }^{\circ} \mathrm{C}$ (less convenient) and 0.2 for negative temperature $\left(T<0{ }^{\circ} \mathrm{C}\right)$ or very high temperature $\left(T>500^{\circ} \mathrm{C}\right.$ ) (very detrimental and energetically costly in practice). The third marker is the compatibility of the process with continuous operation; it is set to 1 for the regenerative swing method (fully-compatible with continuous operation), to 0.5 for the non-regenerative method, and to 0 for external regenerative systems. Non-regenerative methods are based on chemical trap [30] and are not presented here. Although temperature swing adsorption (TSA) could be used to remove the adsorbed impurities from the mixture, this method is limited to low productivities as compared to the PSA. TSA or Vacuum Swing Adsorption (VSA) exhibit more energy consumption than PSA [31], thus these method are not detailed here. The fourth marker is the energetic cost of the process: a value of 1 corresponds to the minimal work for the purification. Agrawal et al. [14] proposed a classification for the energetic consumption of purification processes: membrane $>$ cryogenic. The fifth marker is the gas purity that can be reached with the process, which is in favor of the membrane and EHC processes (both use membranes, in fact, which provides and selects to the separation and therefore high purity of the obtained hydrogen). The results of this quotation are gathered in Fig. 2; they demonstrate that the EHC has many advantages over the other hydrogen purification techniques: EHC offers the best compromise between these five markers.

Another thing that must not be forgotten is, as specified in the previous sections, that the EHC (and the Pd membrane process) are compatible with small units of purification, which render them well-suited for fuel cell vehicles refilling systems.

Table 1

Additional literature information for several hydrogen purification methods.

\begin{tabular}{lccc}
\hline Method & Refs. & Temperature range $\left({ }^{\circ} \mathrm{C}\right)$ & Pressure range \\
\hline Cryogenic & {$[13,14]$} & $(-235)-(-) 46$ & $1-10 \mathrm{bar}$ \\
PSA & {$[15-20]$} & $25-80$ & $1-10 \mathrm{bar}$ \\
Porous membranes & {$[21,22]$} & $25-500$ & $20 \mathrm{bar}$ \\
Palladium membrane & {$[21,26]$} & $350-500$ & $>10 \mathrm{bar}$ \\
Polymeric membrane & {$[23,24]$} & $25-65$ & Vacuum: $10^{-2} \mathrm{mbar}$ \\
Protonic ceramic membrane & {$[27,28]$} & $700-1000$ & $>10 \mathrm{bar}$ \\
\hline
\end{tabular}




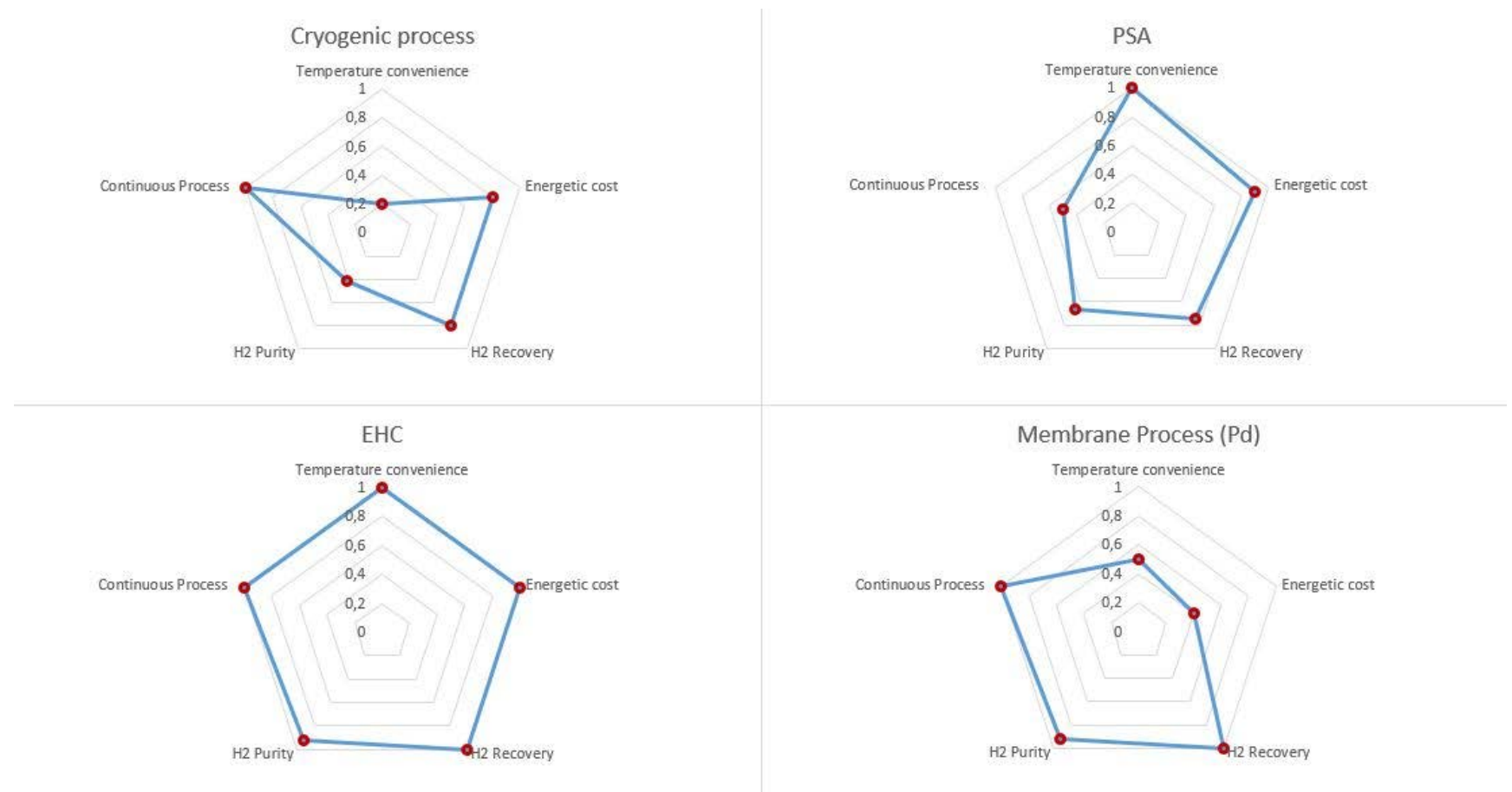

Fig. 2. Comparative diagram of the performances of several hydrogen purification methods.

\section{Thermodynamic comparison of gas compression}

As stated in preamble, most industrial techniques of hydrogen post-treatment upon production use different steps for the purification and the compression. Hereafter are detailed the classical means that are used to compress hydrogen at an industrial scale. Most of them are based on a mechanical compression (MC).

According to Petitpas et al. [32], the ideal gas law is valid until 100 bar for hydrogen $\left(23^{\circ} \mathrm{C}\right)$. At $23^{\circ} \mathrm{C}$ between 100 to 800 bar, the isentropic coefficient $\gamma$ increases. The adiabatic energy loss is undervalued (by $15 \%$ to $20 \%$ ) with the assumption of the ideal gas law versus a real gas. Therefore, the ideal gas assumption presents a non-favorable case for comparison with isothermal compression (Nernst law). In order to simplify the computations of energy losses, this paper present the results with ideal gas law.

\subsection{Mechanical compressor}

\subsubsection{Energy requirements for hydrogen compression}

Currently, mechanical compressors are considered to be the most commonly used in the industry. These systems enable to increase a gas pressure by decreasing its volume using a mechanical force (energy). Both pneumatically and electrically-driven compressors are considered as mechanical compressors (MC). Electrically-driven compressors require a lower energy demand than those driven pneumatically [33]. For multistage compression from room pressure to a final pressure of $20 \mathrm{MPa}$, about $8 \%$ of the higher heating value (HHV) of the transported gas energy content (here hydrogen) is required.
This analysis, which does not include any losses in the electrical power supply system, means that at least 1.08 units of energy must be invested in the compression to obtain 1 unit of hydrogen $\mathrm{HHV}$ at $20 \mathrm{MPa}$. The number increases to 1.12 for compression to $80 \mathrm{MPa}$, a level of pressure that needs to be reached for hydrogen transfer to the proposed $70 \mathrm{MPa}$ standard vehicle tanks of automobiles [34]. If mechanical and electrical losses are also considered, the total electricity needs for hydrogen compression to these pressures may reach $20 \%$ of the HHV hydrogen energy leaving the process. Assuming the real gas using Abel-Noble equation of state, a quick comparison can be done between the HHV for various fuel options with different pressure and state of matter (Fig. 3).

The basic thermodynamic process is described using the adiabatic compression formula (Eq. (3)):

$$
Q_{\mathrm{w}}^{\mathrm{MHC}}=\left[\frac{\gamma}{\gamma-1}\right] p_{1} V_{1}\left[\left(p_{2} / p_{1}\right)^{\gamma-1 / \gamma}-1\right]
$$

where $Q_{\mathrm{w}}^{\mathrm{MHC}}\left(\mathrm{J} \mathrm{kg}^{-1}\right)$ is the specific compression work, $p_{1}(\mathrm{~Pa})$ and $p_{2}(\mathrm{~Pa})$ are respectively the initial and final pressures, $V_{1}\left(\mathrm{~m}^{3}\right.$ $\mathrm{kg}^{-1}$ ) is the initial specific volume and $\gamma$ is the ratio of specific heats, also known as the adiabatic coefficient.

The compression work is different from one gas to another. For example, the adiabatic coefficient of hydrogen is $\gamma=1.41$ and its initial specific volumes is $V_{1}=11.11 \mathrm{~m}^{3} \mathrm{~kg}^{-1}\left(0^{\circ} \mathrm{C}\right)$, while for methane, the adiabatic coefficient is $\gamma=1.31$ and the initial specific volumes is $V_{1}=1.39 \mathrm{~m}^{3} \mathrm{~kg}^{-1}\left(0^{\circ} \mathrm{C}\right)$. As shown in Fig. 4 , hydrogen requires around nine times more energy than methane to be compressed, and 15 times more than air. Besides, the actual compression work is usually slightly larger from the one calculated with the Eq. (3), owing to additional losses, such as flow and friction losses. 


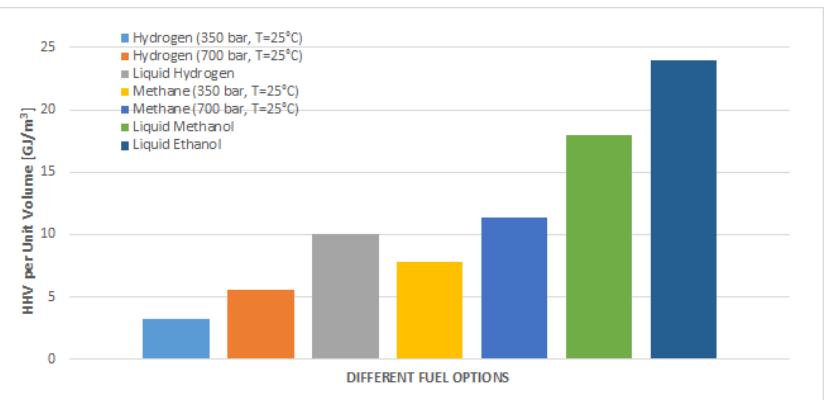

Fig. 3. Volumetric HHV energy density of different fuels; plot constructed from the data of $[35,36]$.

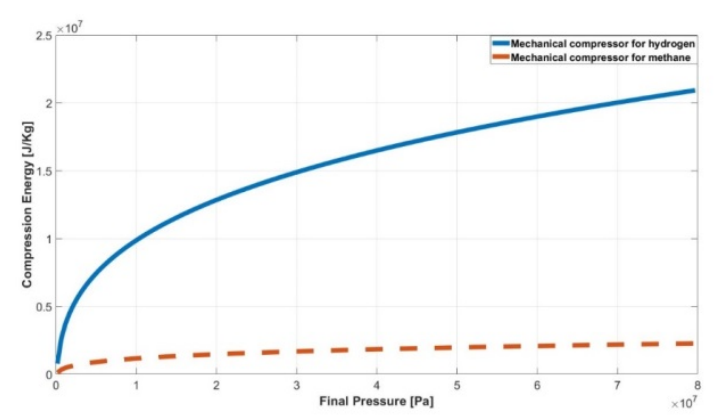

Fig. 4. Adiabatic compression work versus final pressure for hydrogen and methane.

Therefore, one can definitely state that the energy-consumption required for hydrogen mechanical compression is (really) not negligible, and must be taken into account in the overall chain of hydrogen supply.

\subsubsection{Most advanced mechanical compressors}

Mechanical compressors that are specifically used for hydrogen compression can be ranked according to different classifications. Sdanghi et al. [10] have divided the mechanical compressors into the following categories (Fig. 5). Among these, the most innovative (and very interesting) MC that exist currently are the linear compressors and ionic liquid compressors, even if they are not the most used, yet.

\subsection{Linear compressors}

Compared to other compressors, the linear compressor's piston is connected straight to a linear motor coupled with springs. The presence of fewer rotating components simplifies the system, and hence lowers its costs [37]. The piston is usually driven by linear motors with a moving-magnet [38] or a moving-coil. The gas-bearing system between the piston and the cylinder is one of the most obvious advantages for utilizing linear compressors [39], which allows the gas to act as a pad to prevent friction. This methodology also guaranties high level of purity to the outlet gas, due to the absence of lubricants in the system. Moreover, linear compressors are very silent devices. Whatever their advantages, gas bearings can cause piston drift because of the pressure difference between the two sides [40] and the piston motion can also be affected by the temperature or the gas flow due to the absence of a rod-crank assembly.

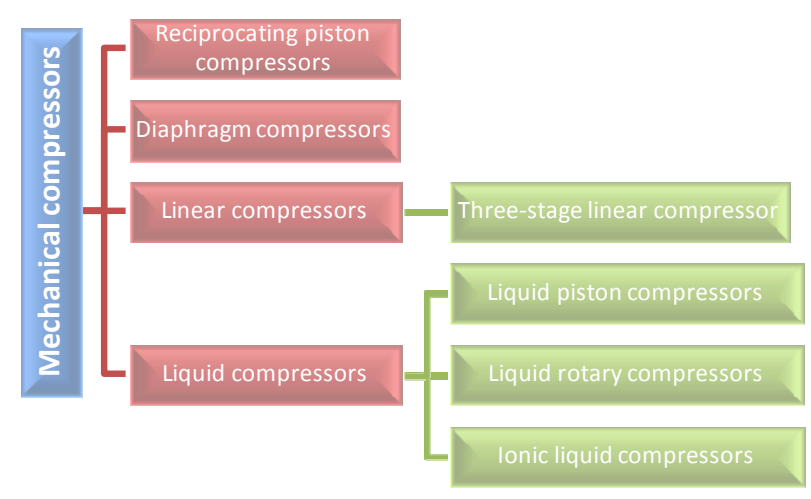

Fig. 5. Different types of the mechanical hydrogen compressor (MHC); diagram constructed from the data of [10].

Linear compressors are commonly used for (small) domestic refrigeration and cryogenic systems [41,42]. The Southwest Research Institute (Texas) has developed a new approach to enhance the applicability of linear compressors at larger scale in hydrogen compression [37]: this project aims to compress hydrogen up to $P_{\text {out }}=87.5 \mathrm{MPa}$ using a system of three linear compressors with a water-based cooling loop. Table 2 summarizes the pressure rise, flow and efficiency of their hydrogen linear compressor.

\subsection{Ionic liquid compressors}

Ionic liquids exhibit uncommon combination of characteristics, which are at the basis of the interest of ionic liquid compressors: low vapor pressure, great lubrication characteristic, high thermal stability, low gas solubility [43]. As a result, ionic liquid compressors display high efficiency and high compression ratio, especially for hydrogen, owing to the negligibly-low solubility of $\mathrm{H}_{2}$ in the appropriately-chosen ionic liquid [44]. These properties make ionic liquid compressors popular [45], e.g. in the field of batteries, fuel cells, solar cells and thermal storage [46]. These systems also guaranty low energy consumption, low capital cost (the ionic liquid, depending on its nature, may be expensive, though), minor noise emission and long durability.

However, the use of ionic liquids holds several drawbacks, such as the high risk of corrosion of metal parts by the ionic liquid, which may decrease the material strength, and therefore induce risks of contamination of the compressed gas and high maintenance costs. There are also some technical disadvantages such as the liquid leaving the chambers with the compressed gas [47] or the cavitation phenomena caused by the gas driven into the liquid. Table 3 recaps the pressure rise, flow, efficiency and specific energy for two different hydrogen ionic liquid compressor systems, one of them being a five-stage

Table 2

Hydrogen linear compressor efficiency.

\begin{tabular}{lcccc}
\hline & $\begin{array}{c}P_{\text {in }} \\
(\mathrm{MPa})\end{array}$ & $\begin{array}{c}P_{\text {out }} \\
(\mathrm{MPa})\end{array}$ & $\begin{array}{c}\text { Flow } \\
\left(\mathrm{Nm}^{3} \mathrm{~h}^{-1}\right)\end{array}$ & $\begin{array}{c}\text { Efficiency } \\
(\%)\end{array}$ \\
\hline $\begin{array}{l}\text { Broerman } \text { et al. } \\
{[37]}\end{array}$ & 2 & $\begin{array}{c}86-95 \\
(3 \text { stage })\end{array}$ & $>112$ & $\begin{array}{c}>73 \\
\text { (adiabatic) }\end{array}$ \\
\hline
\end{tabular}


Table 3

Hydrogen Ionic liquid compressor efficiency.

\begin{tabular}{lccccc}
\hline & $P_{\text {in }}(\mathrm{MPa})$ & $P_{\text {out }}(\mathrm{MPa})$ & Flow $\left(\mathrm{Nm}^{3} \mathrm{~h}^{-1}\right)$ & Efficiency $(\%)$ & Specific energy consumption $\left(\mathrm{kWh} \mathrm{kg}{ }^{-1}\right)$ \\
\hline Van de Ven et al. [47] & 0.1 & 1 & No data & 83.3 (isothermal) & No data \\
Linde Group [48] & $0.33-20$ & 90 (5 stages) & 370 & No data & 2.7 \\
\hline
\end{tabular}

compressor that the company Linde developed to enable compression up to $P_{\text {out }}=90 \mathrm{MPa}$.

\subsection{Thermal hydrogen compression: metal hydrides}

Thermal hydrogen compression is a process based on the reversible insertion (absorption) / de-insertion of hydrogen in a hydride-forming metal. More specifically, it uses reversible heat interactions driven by the combination of a hydride-forming metal with hydrogen into a metal hydride (MH, Eq. 4).

$$
\mathrm{M}(\mathrm{s})+\frac{x}{2} \mathrm{H}_{2}(\mathrm{~g}) \underset{\text { absorption }}{\longrightarrow} \mathrm{MH}_{\mathrm{x}}(\mathrm{s})+Q
$$

where $\mathrm{M}$ is a metal/alloy, (s) relates to the solid and (g) to the gas phases. The absorption reaction corresponds to the exothermic formation of $\mathrm{MH}$; $Q$ is the corresponding released of heat.

According to the literature [49], this method can be considered as promising for the hydrogen industry. In the early 1970s, thermal hydrogen compressors were developed as a good substitute to conventional compressors. The main advantages of the thermal compression are the simple design and easy system operation, which makes it both safe and reliable. Besides, instead of consuming electricity, it can consume waste industrial heat, which greatly decreases the operating costs of the system. Moreover, the costs of the materials and their availability have an essential importance for this technology. In order for the MH compression to be efficient, it requires [49]:

- a high compression ratio;

- high productivity and efficiency;

- long and reliable operation.

Practically, a compromise between these different factors need to be found in order to optimize the performance of this compression. The successful application of MH hydrogen compressors is greatly related to the production costs. As the most expensive components of $\mathrm{MH}$ hydrogen compressors are the metal hydrides and its container, only their optimized production will allow sufficient cost-reduction, and will render this technology commercially-successful. Besides, metal hydrides are very sensitive to some impurities (including oxidant ones like water of $\mathrm{NO}_{x}$ and $\mathrm{CO}_{x}$ ), which makes their coupling mandatory to a very efficient hydrogen purification devices [50,51].

\subsection{Electrochemical hydrogen compression (EHC)}

As stated above, whereas in the most conventional compressors (e.g. mechanical compressors), the purification is separated from the compression process, EHC combines the purification and the compression in one single step. This makes EHC interesting alternatives from usual (purification + com- pression) systems; their intrinsically high efficiency but also the fact they do not use moving parts (except for cooling system) are also to their advantages. As illustrated in Fig. 1, the cathode side is the origin of the compression (and purification) in these devices [52]. According to the research data, only the back-diffusion of hydrogen from the (high-pressure cathode side) and the intrinsic mechanical properties of the membrane cause a pressure limitation and not the electrochemical operating principle of the EHC [53], which means that very high compression ratios are achievable in principle [54].

Studies usually show that efficient proton exchange membrane (PEM)-based EHCs can be built for output pressures ranging from $34<P_{\text {out }}<100$ bars (starting from room pressure). The pressure upgrade depends on the sealing construction and the design of the cell. More practically, the output pressure can be increased by stacking several cells in series (in that case, the overall output pressure increases in cascade from one cell to the other), while the hydrogen flow can be increased using larger units. The literature makes clear that the reduction of materials production cost achieved for the PEM fuel cells (PEMFC) for the last decade can also be applied to PEM hydrogen compressors (PEM-EHC) [53]. Some researchers such as Casati et al. [55] have used a PEMFC to test the different aspects of the PEM-EHC. Besides the cross-cutting aspects of PEM-based technologies, either for fuel cells or electrolyzes, the PEM-EHC has no moving part. Therefore, it does neither generate noise nor vibrations, and no gas-contaminating lubricants are needed in the process [56]. The heat production of the process is small (because both the HER and the HOR are fast reactions in PEM environments [34], at least when the incoming hydrogen gas is pure), inducing low temperature rise upon compression, which implies that the EHC does not need an expensive pre-chilling equipment.

Catalano et al. [57] have demonstrated the maximum efficiency $\eta$ of electrochemical gas compressors, following its mathematical calculation (Eq. (5)):

$$
\eta=\frac{\sqrt{1+\beta}-1}{\sqrt{1+\beta}+1}
$$

where $\beta$ is the figure-of-merit for electro-kinetic compression in the gas phase (equation (6)):

$$
\beta=\left(R T / F^{2}\right)\left(t_{\mathrm{n}}^{2} \sigma / \kappa_{\mathrm{n}}\right)
$$

where $R$ is the gas constant $\left(8.31 \mathrm{~J} \mathrm{~mol}^{-1} \mathrm{~K}^{-1}\right), T$ is the temperature $(\mathrm{K}), F$ is the faraday constant $\left(96487 \mathrm{C} \mathrm{mol}^{-1}\right), t_{\mathrm{n}}$ is the dimensionless transference coefficient of the volatile species ( $\mathrm{H}_{2}$ and methanol, in their study), $\sigma$ is the ionic conductivity (S $\mathrm{m}^{-1}$ ) and $\kappa_{\mathrm{n}}$ is the molar permeability coefficient ( $\mathrm{mol} \mathrm{s}^{-1} \mathrm{~m}^{-1}$ ) for zero current density. Using the estimation for the gas transport properties of Nafion ${ }^{\circledR}$ with pure $\mathrm{H}_{2}$ from Sakai et al. [58] and with $\mathrm{H}_{2}$ and methanol transport from [59], the fig- 
Table 4

Calculation of efficiency for different $\mathrm{Nafion}^{\circledR}$ with pure $\mathrm{H}_{2}$ and $\mathrm{Nafion}{ }^{\circledR}$ with $\mathrm{H}_{2}$ and methanol [57].

\begin{tabular}{lccccc}
\hline Nafion $^{\circledR}$ & $\kappa_{\mathrm{n}}\left(\mathrm{mol} \mathrm{s}^{-1} \mathrm{~m}^{-1}\right)$ & $t_{\mathrm{n}}$ & $\sigma\left(\mathrm{S} \mathrm{m}^{-1}\right)$ & $\beta$ & $\eta(\%)$ \\
\hline Nafion $^{\circledR}$ with pure $\mathrm{H}_{2}$ & $9 \times 10^{-9}$ & $1 / 2$ & 10 & 74 & 79 \\
Nafion ${ }^{\circledR}$ with $\mathrm{H}_{2}$ and & $5 \times 10^{-6}$ & 5 & 4.8 & & \\
methanol & & 20 & 1.2 & 32 & 70 \\
\hline
\end{tabular}

ure-of-merit and the efficiency were calculated as follows (Table 4).

\subsection{Comparison of the compression methods (MHC \& EHC)}

Although EHCs seem to have a very high efficiency, these devices still suffer from disadvantages, such as the (still too) low power density and the (possibly large) over potential needed to dissociate hydrogen at the anode (especially if impure), which have not been taken into account in the previous estimation of the efficiency [57]. Note that the cathode reaction (recombination of protons into $\mathrm{H}_{2}$ at the cathode) is believed to be only mildly limiting the overall process (there are no impurities on the cathode side, because the PEM enables high selectivity in proton transport). Contrary to the MHC, which is accomplished using diaphragm and piston pumps in an adiabatic process, that requires to be divided into stages in order to reduce the heating of the system and increase the efficiency, the $\mathrm{EHC}$ is an isothermal and single-stage process, as claimed by HyET company. HyET has also stated that single-stage electrochemical hydrogen compression can even reach $100 \mathrm{MPa}$ [60] starting from room pressure, a very impressive performance (but obtained for a small demonstration cell: $1 \mathrm{~cm}^{2}$ geometric area). In practice for large units, compression to these high pressure levels will likely be made with several stages of intermediate compression. The thermodynamic process taking place in an EHC is described using the isothermal compression formula. Being admitted that such a purification system is also a compression system, the minimum electrical work needed for the system is the theoretical work of compression, as defined by the Nernst equation [61] (Eq. (7)).

$$
V_{\text {theor }}=\frac{R T}{n F} \ln \left(\frac{P_{2}}{P_{1}}\right)
$$

where $n$ is the mole number (mol), $P_{1}$ is the pressure at the anode (inlet) side and $P_{2}$ is the pressure at the cathode (outlet) side. According to Faraday's law (Eq. (8)):

$$
\dot{m}=\frac{M I}{n F}
$$

where $\dot{m}$ is the hydrogen mass flow $\left(\mathrm{kg} \mathrm{s}^{-1}\right), I$ is the current (A), $M$ is the molar mass $\left(\mathrm{kg} \mathrm{mol}^{-1}\right)$, the power needed for transporting hydrogen is given by equation (9):

$$
W=I V_{\text {theor }}
$$

By combining (Eq. (9)) and (Eq. (7)), the theoretical power needed to transfer hydrogen from the anode to the cathode can be calculated according to equation (10).

$$
W=\frac{\dot{m} R T}{M} \ln \left(\frac{P_{2}}{P_{1}}\right)
$$

Comparing the adiabatic specific compression work (Eq.
(3)) for methane and hydrogen to the hydrogen isothermal specific compression work (Eq. (11)):

$$
Q_{\mathrm{w}}^{\mathrm{EHC}}=\frac{R T}{M} \ln \left(\frac{P_{2}}{P_{1}}\right)
$$

The compression energy is clearly more interesting using isothermal compression, i.e. in a EHC device, versus an $\mathrm{MC}$ compressor (Fig. 6).

\section{Applied aspects of electrochemical compression/ purification}

\subsection{General layout}

Currently, all the electrochemical compression systems involved in the hydrogen industry are described as non-thermal devices. Therefore, the main purpose of most research works developed in this domain is to increase their efficiency. Some researchers have focused on the electrochemical principle of the compression [62] and others have chosen to work on the purification aspects of this process [63,64]. Casati et al. [55] have investigated some fundamental aspects in the EHC using a PEMFC; this work has unveiled some performing parameters of the system, such as:

The membrane hydration is a critical issue: galvanostatic operating condition can damage the membrane due to the improper water management. Therefore, tensiostatic operating condition must be favored.

The feed flow has an important impact on the amount of hydrogen recovered. The recovered fraction rises when the inlet hydrogen flow rate decreases. The recovery rate is maximum when the inlet flow of hydrogen is equal to the flow rate trough the membrane (determined by the cell current). As a consequence, this maximum is determined by the hydrogen production (at the outlet).

The specific energy consumption depends only on the applied voltage, which is divided into: thermodynamic potential, due to the compression ratio of the hydrogen; kinetic potential, that depends on cell current, or in other words the flowrate of hydrogen treated across the MEA (overvoltage); dissipative potential, defined by the useless forces (Ohmic drop).

Besides these previous results relative to the EHC performance, the selective permeability of the membrane is another advantage of this process. Only purified hydrogen and water vapor are present at the cathode [53]. As regards to the elec-

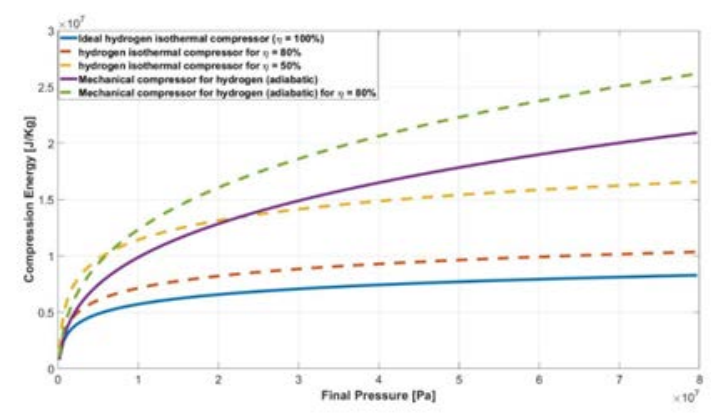

Fig. 6. Compression energy of isothermal compression versus adiabatic compression $\left(25^{\circ} \mathrm{C}\right)$. 
trocatalysis, it depends on the proper organization of three main components in so-called porous electrodes [65]: carbon, Nafion ${ }^{\circledR}$ and the electrocatalyst (active layer). The electrocatalyst is often a noble metal such as platinum or its alloys/composites, chosen for its high kinetics towards the hydrogen oxidation reaction and hydrogen evolution reaction (HOR and HER). The different materials need to be chosen depending on the system operating conditions (targeted performances), and the nature of the impurities in the hydrogen feed. More emphasis on these electrocatalytic aspects will be discussed in details in part II of the present contribution "Electrochemical hydrogen compression and purification versus competing technologies - Part II: challenges in electrocatalysis".

\subsection{Water management}

Water transport through a proton exchange membrane (PEM) is a critical issue for both a fuel cell and an electrochemical compressor. Most of the studies that focused on water management were related to the case of fuel cells (FC). Water transport inside the membrane is induced by three mechanisms: the electro-osmotic drag caused by proton transport (from the anode to the cathode side), the back-diffusion flux (from the cathode to the anode side) and the pressure gradient due to the pressure rise of the compression at the cathode side (in the case of EHC). The difference between the FC and the EHC for this particular issue is that at the cathode side of a FC, water is produced by the electrochemical reaction, which might cause an excess of water in the system (flooding); in the case of an EHC water is not involved in any of the reactions at stake (Fig. 1); this does however not mean that water is useless to the operation of an EHC. Indeed, the lack of water production coupled to the need for non-negligible proton transport in the PEM from the anode to the cathode (being admitted that protons are accompanied by water molecules and that the present membranes need to be well-hydrated to promote fast proton transport) might cause a water drainage in the membrane; if uncontrolled, it will eventually stop any proton transport, hence the compression process.

At the equilibrium, the water content parameter is used to describe the water quantity in the membrane. Both Zawodzinksi et al. [66] and Springer et al. [67] have presented a correlation between the equilibrium water vapor pressure and the water content value for Nafion ${ }^{\circledR}$ at atmospheric pressure and a temperature of $30^{\circ} \mathrm{C}$. Hinatsu et al. [68] demonstrated an empirical formula describing the previous correlation at a temperature of $80{ }^{\circ} \mathrm{C}$ and Ge et al. [69] gave an equation predicting the water content in a PEM for $30^{\circ} \mathrm{C}<T<80^{\circ} \mathrm{C}$. As for Kusoglu et al. [70], they talked about the internal balance between chemical and mechanical forces determining the water content in Nafion ${ }^{\circledR}$ membranes. For the diffusion coefficient, it is also a function of the water content; Majsztrik et al. [71] have provided insight into the different measurement methods considered in the literature to quantify diffusion, whilst distinguishing sorption and desorption effects. During the electrochemical pumping in addition with thermodynamic equilibrium, mass, momentum and charge balance must be solved.
Therefore, steady-state mass balance in the membrane for incompressible fluid flow simplifies the water equation as follows (Eq. (12)):

$$
D_{\mathrm{H}_{2} \mathrm{O}} \Delta c_{\mathrm{H}_{2} \mathrm{O}}=\vec{v}_{\mathrm{m}} \cdot \vec{\nabla} c_{\mathrm{H}_{2} \mathrm{O}}
$$

where $c_{\mathrm{H} 2 \mathrm{O}}$ is the bulk concentration of water in the membrane, $\vec{v}_{\mathrm{m}}$ is the velocity inside the membrane and the term $D_{\mathrm{H} 2 \mathrm{O}}$ is the diffusion coefficient.

The momentum balance is described by a form of Schlögl's equation of motion; electric potential and pressure gradients generate convection within the pores of the ion-exchange membrane [72], as expressed by Eq. (13).

$$
\vec{v}_{\mathrm{m}}=-\frac{\kappa_{\Phi}}{\mu} z_{\mathrm{f}} c_{\mathrm{f}} F \frac{\vec{j}}{\sigma}-\frac{\kappa_{\mathrm{p}}}{\mu} \vec{\nabla} p
$$

where $\mu$ denotes the water viscosity, $\kappa_{\Phi}$ is the electro-kinetic permeability, $z_{\mathrm{f}}$ is the fixed-charge number in the membrane, $c_{\mathrm{f}}$ is the fixed-charge concentration, $\kappa_{p}$ is the hydraulic permeability, $\sigma^{\mathrm{m}}$ is the ionic conductivity and $\vec{j}$ is the current inside the membrane.

This type of equation can be difficult to solve due to the different parameters that should be taken into account, such as the current density, the pressure, the water concentration and the membrane characteristics. Modeling of the EHC properties therefore requires a clear distinction between the internal driving forces for water fluxes and external conditions [73]. According to them, the hydrogen dehumidification is an interesting issue observed during compression. Compression of the gases leads to the pressure rise of the hydrogen at the cathode side unlike for water vapor that is condensed.

\subsection{Gas permeation}

As two compartments with different partial pressure are separated by a membrane, permeation of any species could occur downward the partial pressure gradient. Gas permeation is therefore driven by partial pressure gradient, and also depends on the operating conditions, such as temperature and relative humidity (water management), and is determined by the nature of the membrane and its thickness. Kocha et al. [74] described the principle of gas permeation and gave the expression of gas permeation rate $N_{\mathrm{i}}\left(\mathrm{mol} \mathrm{s}^{-1} \mathrm{~m}^{-2}\right)$ of species $i$ (Eq. (14)):

$$
N_{\mathrm{i}}=D_{\mathrm{i}} \frac{H_{\mathrm{i}}^{\mathrm{h}} p_{\mathrm{i}}^{\mathrm{h}}-H_{\mathrm{i}}^{\mathrm{l}} p_{\mathrm{i}}^{\mathrm{l}}}{\delta}
$$

and the definition of $k_{\mathrm{i}}$, the gas molar permeability coefficient, (mol m${ }^{-1} \mathrm{~s}^{-1} \mathrm{~Pa}^{-1}$ ) (Eq. (15)):

$$
k_{i}=D_{\mathrm{i}} H_{\mathrm{i}}
$$

with $H_{\mathrm{i}}$ the solubility coefficient, (mol m-3 $\left.\mathrm{Pa}^{-1}\right), D_{\mathrm{i}}$ the effective diffusion coefficient, $\mathrm{m}^{2} \mathrm{~s}^{-1}, p_{\mathrm{i}}$ the partial pressure of gas $(\mathrm{Pa})$, and $\delta$ the thickness of the membrane. These expressions demonstrate that the solubility and diffusion coefficient of the species are of equal importance in the permeation phenomenon.

\subsection{Hydrogen back-diffusion}


A lot of study exist on hydrogen crossover in PEMFC ([74-78], among others), due to its sever impact on both the efficiency and durability of the fuel cell. For example, Brunetti et al. [77] evaluated mass-transport, including hydrogen crossover, for Nafion ${ }^{\circledR} 117$ and a cross-linked home-made SPEEK membrane. The gas permeability coefficient depends on temperature, relative humidity and nature of the membrane, while the transport is strongly depending on the water content and on the hydrothermal history of membrane. Truc et al. [76] proposed a numerical model including hydrogen crossover and the dependence of permeability with membrane water content and temperature.

In addition, the hydrogen back diffusion is directly related to the pressure gradient. If only electrochemical purification is targeted, the cell could be operated by applying a total pressure gradient of zero across the PEM [79]. For a one-step electrochemical compressor, the total pressure gradient varies greatly from one experiment to another. Indeed, several cells are usually included in a stack: even if the overall compression ratio is specified, it is difficult to know the pressure difference on either side of the membrane for one cell within the stack. It is nevertheless commonly known that 50 bar is a large pressure gradient for low-temperature commercial PEMs [73]. At laboratory scale, with reinforced or high-temperature membranes, higher gradient have been obtained [54], hence large compression (a positive effect). However, such large gradients enhance gas permeation and back-diffusion (a negative effect). All is therefore a matter of compromise.

For an EHC compressor with a standard membrane, back-diffusion does not limit the compression ratio. The faradaic equivalent current $\left(j_{\text {feq }}\right)$ can be estimated from the hydrogen permeation rate, and it is low in front of the current imposed on the cell. Bessarabov et al. [73] showed some experimental data for commercial low temperature (for the differential pressure, $\Delta P=50$ bar, the maximum value is $j_{\mathrm{f}, \mathrm{eq}}<80 \mathrm{~mA}$ $\mathrm{cm}^{-2}$ ) and high temperature membranes (for $\Delta P=250 \mathrm{bar}, j \mathrm{f}$,eq $<10 \mathrm{~mA} \mathrm{~cm}^{-2}$ ).

Accordingly, Baik et al. [78] showed that the equivalent current due to hydrogen crossover is below $j_{\text {f,eq }}<2 \mathrm{~mA} \mathrm{~cm}^{-2}$. These authors gave an empirical model thanks to multiple linear regressions (Eq. (16)):

$$
\varphi=a_{0}+a_{1} T+a_{2} R H+a_{3} k_{H_{2}}+\frac{a_{3}}{\ln (\delta)}
$$

where $\varphi$ is the hydrogen crossover rate, $R H$ is the Relative humidity and $\delta$ is the membrane thickness. Of course, this empirical model is validated only for moderate gradient for Nafion ${ }^{\circledR}$ membranes thickness from $135<\delta<258 \mu$ m.

The permeability coefficient for low temperature membrane PFSA $([55,73,74])$ varies between $2.10^{-14}<k_{\mathrm{H} 2}<5.10^{-14} \mathrm{~mol}$ $\mathrm{m}^{-1} \mathrm{~s}^{-1} \mathrm{~Pa}^{-1}$. Its value is mainly conditioned by the state of hydration of the membrane and the operating temperature of the cell. According to Eqs. (14) and (15) an estimation is calculated, using mean value of permeability coefficient $\left(k_{\mathrm{H} 2}=3.10^{-14} \mathrm{~mol}\right.$ $\mathrm{m}^{-1} \mathrm{~s}^{-1} \mathrm{~Pa}^{-1}$ ) for Nafion ${ }^{\circledR} 117$ (thickness $=183 \mu \mathrm{m}$ ) and $\Delta P=50$ bar. With these values, the equivalent current of hydrogen crossover flow is then: $j_{\mathrm{f}, \mathrm{eq}}=16 \mathrm{~mA} \mathrm{~cm}^{-2}$, which is a mere $3 \%$ of the current imposed in the cell at $j=0.5 \mathrm{~A} \mathrm{~cm}^{-2}$, and is negligible for larger cell current densities (which is targeted in practice).

Nevertheless, as molecular hydrogen back-diffusion reduces the efficiency of the hydrogen pump and also impacts the hydrogen purity, several strategies of mitigation of the back-diffusion have been suggested:

Add a molecular hydrogen barrier (this strategy is used by HyET), or a modified PEM [80].

Avoid excessive pressure differences on either side of a membrane and use stack of cell for the overall compressor (several steps of (intermediate) compression).

Find an optimal value of current density and adapt water management to avoid permeate backflow and electrical resistance.

\subsection{Gas permeation of impurities and other gas}

At that stage, one has to underline the advantages of hydrogen pump against (non-electrochemical) membrane separation: the selectivity is imposed by the difference between the migration flow of proton and the gas permeation of impurities; the former flow is driven by the current density, while the latter depends on the gradient of partial pressure. For example in EHC, Bouwman et al. [54] extract hydrogen (10\%) from nitrogen with a good yield of extraction. Lee et al. [79], achieves high-purity hydrogen from mixture $\left(\mathrm{N}_{2}, \mathrm{CO}_{2}, \mathrm{H}_{2}\right)$ from $10 \%$ to $90 \%$ of hydrogen. Table 5 represents the gas permeability coefficient and diffusivity coefficient for the usual impurities for different operating conditions.

Table 5

Permeability and diffusion of gases in several Nafion ${ }^{\circledR}$ membranes.

\begin{tabular}{|c|c|c|c|c|c|}
\hline Gas & Gas permeability coefficient $k_{\mathrm{i}}\left(\mathrm{mol} \mathrm{m}^{-1} \mathrm{~s}^{-1} \mathrm{~Pa}^{-1}\right)$ & Diffusivity coefficient $D_{\mathrm{i}}\left(\mathrm{m}^{2} \mathrm{~s}^{-1}\right)$ & Type of Nafion ${ }^{\circledR}$ & Operating conditions & Ref. \\
\hline$\overline{\mathrm{H}_{2}}$ & $4.1610^{-15}$ & $10410^{-12}$ & Dry N211 & $35^{\circ} \mathrm{C}, 2 \mathrm{~atm}$ & [81] \\
\hline $\mathrm{O}_{2}$ & $6.0110^{-16}$ & $5.910^{-12}$ & Dry N211 & $35^{\circ} \mathrm{C}, 2 \mathrm{~atm}$ & [81] \\
\hline $\mathrm{CO}$ & No data & $18.010^{-12}$ & Humidified N112 & $35^{\circ} \mathrm{C}$ & [82] \\
\hline \multirow{2}{*}{$\mathrm{CO}_{2}$} & $1.3610^{-15}$ & $2.710^{-12}$ & Dry N211 & $35^{\circ} \mathrm{C}, 2 \mathrm{~atm}$ & [81] \\
\hline & $4.810^{-15}$ & $14.610^{-12}$ & Dry N115 & $70^{\circ} \mathrm{C}, 1 \mathrm{~atm}$ & [79] \\
\hline \multirow{2}{*}{$\mathrm{N}_{2}$} & $1.410^{-16}$ & $1.810^{-12}$ & Dry N211 & $35^{\circ} \mathrm{C}, 2 \mathrm{~atm}$ & [81] \\
\hline & $1.2510^{-15}$ & $6.210^{-12}$ & Dry N115 & $70^{\circ} \mathrm{C}, 1 \mathrm{~atm}$ & [79] \\
\hline $\mathrm{H}_{2} \mathrm{~S}$ & No data & $8.4810^{-12}$ & Humidified N112 & $35^{\circ} \mathrm{C}$ & [82] \\
\hline $\mathrm{CH}_{4}$ & $4.9410^{-17}$ & $0.4510^{-12}$ & Dry N211 & $35^{\circ} \mathrm{C}, 2 \mathrm{~atm}$ & [81] \\
\hline \multirow{2}{*}{$\mathrm{NH}_{3}$} & $35.710^{-14}$ & No data & Humidified Nafion & $50^{\circ} \mathrm{C}, 1 \mathrm{~atm}$ & [83] \\
\hline & $63.710^{-14}$ & $110^{-8}$ & No data & $100^{\circ} \mathrm{C}, 2 \mathrm{~atm}$ & {$[84]$} \\
\hline
\end{tabular}




\subsection{Operating conditions}

The operating conditions $\left(T, \Delta P, j, U_{\text {cell }}\right)$ of the system depend on the purpose of the utilization.

When only compression is targeted, optimal energy consumption is obtained for a cell current density of $j=0.5 \mathrm{~A} \mathrm{~cm}^{-2}$, and the corresponding cell voltage is close to $U_{\text {cell }}=200 \mathrm{mV}$ (cell resistance is ca. $0.3 \Omega \mathrm{cm}^{2}<R_{\text {cell }}<0.4 \Omega \mathrm{cm}^{2}$ [33]) and the pressure gradient $(\Delta P)$ between both chambers rises to 50 bars at $80{ }^{\circ} \mathrm{C}$. From a thermodynamic point of view, operating at large pressure gradient enhances the benefit of EHC over mechanical compressor.

If the device is used for the purification as well, the required current density shall reach $j=2 \mathrm{~A} \mathrm{~cm}^{-2}$ in order to compete with the existing (non-electrochemical) membrane compression systems, and the cell voltage shall be maintained at a reasonably-low value, typically below $1 \mathrm{~V}\left(\right.$ e.g. $\left.U_{\text {cell }} \cong 0.72 \mathrm{~V}\right)$.

In order to achieve the treatment flow, the choice of the surface area is directly related to the operating current density and the MEA resistivity. For example, for a lower current density the surface area shall be larger, but this is a balance between the capital cost (geometric area of the membrane and electrodes) and the operating costs (cell voltage, which directly depends on the applied current density).

\section{Conclusion: why EHC is relevant for hydrogen purification/compression and why they need adapted electrocatalysts}

The present contribution highlights that, among the different means to purify and compress hydrogen, the EHC exhibits a wealth of assets. This system appears to be the best compromise if one needs to simplify the purification/compression steps of hydrogen. Compared to classical means of hydrogen purification, the EHC combines a low energetic cost, high $\mathrm{H}_{2}$ recovery and purity, little maintenance, low cost and low temperature of operation, which neither the pressure swing adsorption, the cryogenic nor the membrane processes can do. Unlike the widely-used mechanical compressor, EHCs are compatible with an efficient compression even for small systems, do not lead to contamination of the output hydrogen gas and exhibit moderate capital and operational costs. On the side of compression, EHC systems are also of lower cost, and higher efficiency. Last but not least, EHC can do both the purification and compression in a single system (if not a single cell).

In addition, this system is compact and easily adaptable, which allows use on new applications. Barbir et al. [85], operate EHC for recirculation of hydrogen in a fuel cell stack, EHC cell are inserted between fuel cell of the stack avoiding additional pipe. In the same way, EHC should be used for recycling of exhaust gas of industrial processes (for example semi-conductor industries) to increase sustainability because EHC is a device easy for adapting to different exhaust flow and separate hydrogen even at low concentration.

Despite their numerous assets for the purification and compression of hydrogen, electrochemical hydrogen compressors, in order to be competitive to their mechanical/thermal counterparts, need to operate at high current density (above $j=1 \mathrm{~A}$ $\mathrm{cm}^{-2}$ ) at a cell voltage below $U_{\text {cell }}=0.25 \mathrm{~V}$, which remains challenging with an impure feed of hydrogen; these objectives are yet to be met with pure hydrogen inlet [56]. In other words, the needs for EHC to operate at very high current density (likely

\section{Graphical Abstract}

Chin. J. Catal., 2020, 41: 756-769 doi: S1872-2067(19)63404-2

\section{Electrochemical hydrogen compression and purification versus competing technologies: Part I. pros and cons}

Maha Rhandi, Marine Trégaro, Florence Druart, Jonathan Deseure, Marian Chatenet* Univ. Grenoble Alpes, Univ. Savoie Mont Blanc, France

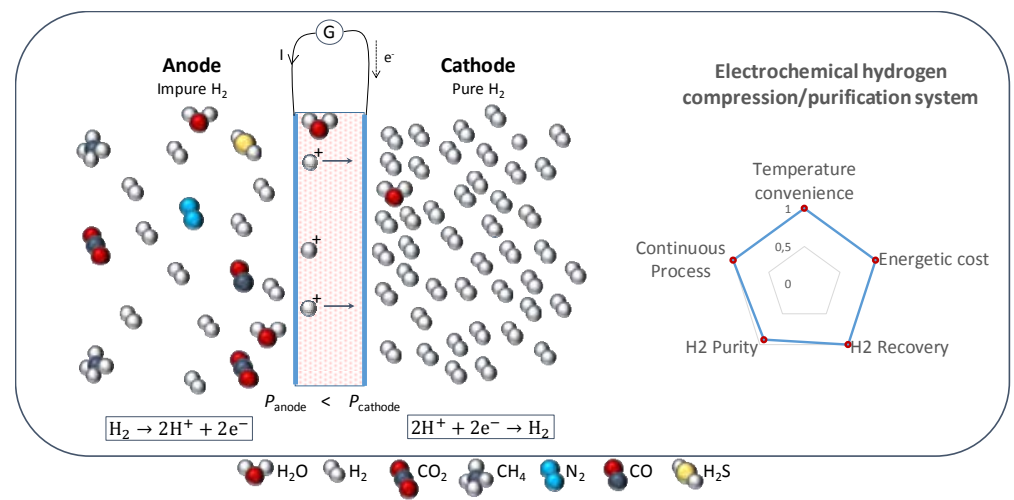

This contribution details the means available today for hydrogen purification and compression. It shows that among the available technologies, the electrochemical hydrogen compressor has numerous advantages compared to the classical technologies presently used in the industry. 
above $j=2 \mathrm{~A} \mathrm{~cm}^{-2}$ or even $j=5 \mathrm{~A} \mathrm{~cm}^{-2}$ ), low cell voltage (likely below $U_{\text {cell }}=0.5 \mathrm{~V}$ ) and high differential pressure per cell (likely $\Delta P=50-70$ bar) to be (economically) competitive. The electrochemical hydrogen purification and compression requires to employ very efficient core materials for the EHC. This is true for the membrane, that ensures the gas separation, hence the purity, and enables the compression, but also for the electrocatalysts, at least the one use in the anode of the first stage of the device, i.e. the one that operates under impure hydrogen. This electrocatalyst (at the anode side of the purification cell) not only must demonstrate very high HOR activity, but also be very tolerant to the poison molecules. The part II of the present contribution "Electrochemical hydrogen compression and purification versus competing technologies - Part II: challenges in electrocatalysis" will address these aspects of electrocatalysis applied to EHC used in the purification and compression of hydrogen.

\section{Acknowledgments}

The authors thank the Auvergne Rhône-Alpes region for the funding of the PhD thesis of Marine Trégaro. Part of the work has been performed within the framework of the Centre of Excellence of Multifunctional Architectured Materials "CEMAM" no. ANR-10-LABX-44-01. Both MR and MT make their PhD in the frame of the Eco-Sesa project, funded by IDEX Université Grenoble Alpes.

\section{Nomenclature}

$c_{f} \quad$ Fixed charge site concentration $\left(\mathrm{mol} \mathrm{cm}^{-3}\right)$

$C_{\mathrm{H}_{2} \mathrm{O}} \quad$ Water concentration $\left(\mathrm{mol} \mathrm{m}^{3}\right)$

$D \quad$ Diffusion coefficient $\left(\mathrm{m}^{2} \mathrm{~s}^{-1}\right)$

EHC Electrochemical hydrogen compressor

$F \quad$ Faraday's constant $\left(\mathrm{C} \mathrm{mol}^{-1}\right)$

HHV Higher Heating Value

$H_{i} \quad$ Solubility coefficient, $\left(\mathrm{mol} \mathrm{m}^{-3} \mathrm{~Pa}^{-1}\right)$

I $\quad$ Current (A)

$j \quad$ Current density $\left(\mathrm{A} \mathrm{cm}^{-2}\right)$

$k_{\mathrm{i}} \quad$ Gas permeability coefficient $\left(\mathrm{mol} \mathrm{m}^{-1} \mathrm{~s}^{-1} \mathrm{~Pa}^{-1}\right)$

$\dot{m} \quad$ Hydrogen mass flow $\left(\mathrm{kg} \mathrm{s}^{-1}\right)$

$M \quad$ Molar mass $\left(\mathrm{kg} \mathrm{mol}^{-1}\right)$

MEA Membrane Electrode Assembly

MHC Mechanical hydrogen compressor

$N_{i} \quad$ Gas permeation rate $\left(\mathrm{mol} \mathrm{s}^{-1} \mathrm{~m}^{-2}\right)$

$n \quad$ Mole number (mol)

$p_{i} \quad$ Pressure (Pa)

$\triangle P \quad$ Differential pressure (Pa)

PEM Proton Exchange Membrane

PEMFC Proton exchange membrane fuel cell

PFSA Perfluorosulfonic acid

PSA Pressure Swing Adsorption

$Q_{w} \quad$ Specific compression work $\left(\mathrm{kg}^{-1}\right)$

$R \quad$ Gas constant $\left(\mathrm{J} \mathrm{mol}^{-1} \mathrm{~K}^{-1}\right)$

RH Relative humidity

$T$ Temperature (K)

$t_{\mathrm{n}} \quad$ Dimensionless transference coefficient of volatile species
TSA Temperature Swing Adsorption

$U_{\text {cell }} \quad$ Cell voltage (V)

$v_{\mathrm{m}} \quad$ Velocity inside the membrane $\left(\mathrm{m} \mathrm{s}^{-1}\right)$

$V_{1,2} \quad$ Initial specific volume $\left(\mathrm{m}^{3} \mathrm{~kg}^{-1}\right)$

$Z_{\mathrm{f}} \quad$ Charge of fixed sites

$\beta \quad$ Figure-of-merit in the gas phase

$\delta \quad$ Membrane thickness (m)

$\gamma \quad$ Specific heats ratio (adiabatic coefficient)

$\kappa_{\Phi} \quad$ Electro kinetic permeability $\left(\mathrm{cm}^{2}\right)$

$\kappa_{\mathrm{p}} \quad$ Hydraulic permeability $\left(\mathrm{cm}^{2}\right)$

$\kappa_{\mathrm{n}} \quad$ Molar permeability coefficient $\left(\mathrm{mol} \mathrm{s}^{-1} \mathrm{~m}^{-1}\right)$

$\lambda \quad$ Water content in the membrane

$\eta \quad$ Efficiency (\%)

$\rho \quad$ Water density $\left(\mathrm{kg} \mathrm{m}^{-3}\right)$

$\sigma \quad$ Ionic conductivity $\left(\mathrm{S} \mathrm{m}^{-1}\right)$

$\varphi \quad$ Hydrogen crossover rate $\left(\mathrm{mol} \mathrm{s}^{-1} \mathrm{~cm}^{-2}\right)$

$\mu \quad$ Water viscosity $\left(\mathrm{kg} \mathrm{m}^{-1} \mathrm{~s}^{-1}\right)$

\section{Superscripts \& subscripts}

$\begin{array}{ll}\text { eq } & \text { Equivalent } \\ f & \text { Faradaic } \\ \text { i, n } & \text { Species } \\ \text { h } & \text { High pressure } \\ \text { l } & \text { Low pressure } \\ \text { m } & \text { Membrane } \\ \text { w } & \text { Work }\end{array}$

References

[1] A. F. Ghoniem, Prog. Energy Combus. Sci., 2011, 37, 15-51.

[2] N. A. Kelly, T. L. Gibson, D. B. Ouwerkerk, Int. J. Hydrogen Energy, 2008, 33, 2747-2764.

[3] www.energy.gov, Last access: Feb 2, 2019.

[4] M. Yáñez, A. Ortiz, B. Brunaud, I. E. Grossmann, I. Ortiz, Appl. Energy, 2018, 231, 777-787.

[5] T. da Silva Veras, T. S. Mozer, D. da Costa Rubim Messeder dos Santos, A. da Silva César, Int. J. Hydrogen Energy, 2017, 42, 2018-2033.

[6] I. Dincer, C. Acar, Int. J. Hydrogen Energy, 2015, 40, 11094-11111.

[7] J.-P. Magnin, J. Deseure, Appl. Energy, 2019, 239, 635-643.

[8] ISO 14687-2: 2012, 2012.

[9] ISO 14687-3: 2014, 2014.

[10] G. Sdanghi, G. Maranzana, A. Celzard, V. Fierro, Renew. Sustainable Energy Rev., 2019, 102, 150-170.

[11] J. Bonjour, J.-B. Chalfen, F. Meunier, Ind. Eng. Chem. Res., 2002, 41, 5802-5811.

[12] F. D. Rossini, Pure Appl. Chem., 1970, 22, 555-570.

[13] G. Q. (UOP Miller Tarrytown, NY (US)) and J. (Union C. B. Stoecker N. V. Antwerp (BE)), Research Org.: None, 1989.

[14] R. Agrawal, S. R. Auvil, S. P. DiMartino, J. S. Choe, J. A. Hopkins, Gas Sep. Purif., 1988, 2, 9-15.

[15] S. Sircar, T. C. Golden, Sep. Sci. Technol., 2000, 35, 667-687.

[16] M. Mondal, A. Datta, Int. J. Energy Res., 2017, 41, 448-458.

[17] A. Abdeljaoued, F. Relvas, A. Mendes, M. H. Chahbani, J. Environ. Chem. Eng., 2018, 6, 338-355.

[18] V. I. Agueda, J. A. Delgado, M. A. Uguina, P. Brea, A. I. Spjelkavik, R. Blom, C. Grande, Chem. Eng. Sci., 2015, 124, 159-169. 
[19] J. Xiao, L. Fang, P. Bénard, R. Chahine, Int. J. Hydrogen Energy, 2018, 43, 13962-13974.

[20] A. Yokozeki, M. B. Shiflett, Appl. Energy, 2007, 84, 351-361.

[21] N. A. Al-Mufachi, N. V. Rees, R. Steinberger-Wilkens, Renew. Sustainable Energy Rev., 2015, 47, 540-551.

[22] M. Hong, S. Li, J. L. Falconer, R. D. Noble, J. Membrane Sci., 2008, 307, 277-283.

[23] R. D. Noble, S. A. Stern, Ed., Membrane separations technology: principles and applications, 2nd. impression. Elsevier: Amsterdam, 1995.

[24] D. Bastani, N. Esmaeili, M. Asadollahi, J. Ind. Eng. Chem., 2013, 19, 375-393.

[25] P. C. K. Vesborg, T. F. Jaramillo, RSC Adv., 2012, 2, 7933.

[26] M. D. Dolan, D. M. Viano, M. J. Langley, K. E. Lamb, J. Membrane Sci., 2018, 549, 306-311.

[27] Z. Zhu, J. Hou, W. He, W. Liu, J. Alloys Compd., 2016, 660, 231-234.

[28] E. Rebollo, C. Mortalo, S. Escolastico, S. Boldrini, S. Barison, J. M. Serra, M. Fabrizio, Energy Environ. Sci., 2015, 8, 3675-3686.

[29] J. M. Sedlak, J. F. Austin, A. B. Laconti, Int. J. Hydrogen Energy, 1981, $6,45-51$.

[30] R. L. Michael, Grant, Robert, Bruce, R. Lambert Michael and Grant, Robert, Bruce, 04-0ct-2007.

[31] A. Golmakani, S. Fatemi, J. Tamnanloo, Sep. Purif. Technol., 2017, 176, 73-91.

[32] G. Petitpas, S. M. Aceves, Int. J. Hydrogen Energy, 2014, 39, 20319-20323.

[33] W. Vielstich, Ed., Fuel cell technology and applications: pt. 1, Reprinted. Wiley: Chichester, 2007.

[34] W. Vielstich, H. Yokokawa, H. Gasteiger, Eds., Advances in Electrocatalysis, Materials, Diagnostics and Durability; part 2. Wiley: Chichester, 2009.

[35] A. Midilli, M. Ay, I. Dincer, M. A. Rosen, Renew. Sustainable Energy Rev., 2005, 9, 255-271.

[36] R. Khaksarfard, M. R. Kameshki, M. Paraschivoiu, Shock Waves, 2010, 20, 205-216.

[37] E. L. Broerman, J. Bennett, N. Poerner, D. Strickland, J. Helffrich, S. Coogan, A. Rimpel, P. Bueno, DOE Hydrogen and Fuel Cells Program. FY 2015 Annual Progress Report, 2016.

[38] H. Jiang, K. Liang, Z. Li, Mechan. Sys. Signal Processing, 2019, 121, 828-840.

[39] R. L. Unger, Proceedings of International Compressor Engineering, 1998.

[40] K. Liang, R. Stone, M. Dadd, P. Bailey, Int. J. Refrig., 2016, 66, $32-40$.

[41] K. Liang, R. Stone, M. Dadd, P. Bailey, Int. J. Refrig., 2014, 40, 450-459.

[42] K. Liang, Int. J. Refrig., 2017, 84, 253-273.

[43] N. A. Kermani, I. Petrushina, A. Nikiforov, J. O. Jensen, M. Rokni, Int. J. Hydrogen Energy, 2016, 41, 16688-16695.

[44] Z. Lei, C. Dai, B. Chen, Chem. Rev., 2014, 114, 1289-1326.

[45] S. Werner, M. Haumann, P. Wasserscheid, Annu. Rev. Chem. Biomol. Eng., 2010, 1, 203-230.

[46] T. Predel, E. Schlücker, P. Wasserscheid, D. Gerhard, W. Arlt, Chem. Eng. Technol., 2007, 30, 1475-1480.

[47] J. D. Van de Ven, P. Y. Li, Appl. Energy, 2009, 86, 2183-2191.

[48] M. Mayer, A3PS Conference, 2014.

[49] M. V. Lototskyy, V. A. Yartys, B. G. Pollet, R. C. Bowman, Int. J. Hydrogen Energy, 2014, 39, 5818-5851.

[50] V. A. Yartys, G. Vijayaprasath, R. Murugan, S. Asaithambi, G. Anandha Babu, P. Sakthivel, T. Mahalingam, Y. Hayakawa, G. Ravi, Appl. Phys. A, 2016, 122, 122.
[51] F. Laurencelle, Z. Dehouche, F. Morin, J. Goyette, J. Alloys Compd, 2009, 475, 810-816.

[52] M. Bampaou, K. D. Panopoulos, A. I. Papadopoulos, P. Seferlis, S. Voutetakis, Chem. Eng. Trans., 2018, 70, 1213-1218.

[53] R. Ströbel, M. Oszcipok, M. Fasil, B. Rohland, L. Jörissen, J. Garche, J. Power Sources, 2002, 105, 208-215.

[54] P. J. Bouwman, J. Konink, D. Semerel, L. Raymakers, M. Koeman, W. Dalhuijsen, E. Milacic, M. Mulder, ECS Trans., 2014, 64, 1009-1018.

[55] C. Casati, P. Longhi, L. Zanderighi, F. Bianchi, J. Power Sources, 2008, 180, 103-113.

[56] H. Monjid, DOE Hydrogen \& Fuel Cells Program, 14-Jun-2018.

[57] J. Catalano, A. Bentien, D. N. Østedgaard-Munck, S. Kjelstrup, J. Membrane Sci., 2015, 478, 37-48.

[58] T. Sakai, H. Takenaka, N. Wakabayashi, Y. Kawami, E. Torikai, J. Electrochem. Soc., 1985, 132, 1328-1332.

[59] R. P. W. J. Struis, S. Stucki, M. Wiedorn, J. Membrane Sci., 1996, 113, 93-100.

[60] P. Bouwman, Fuel Cells Bull., 2014, 2014, 12-16.

[61] L. Lipp, DOE--FCE003727, 1235441, 2016.

[62] B. Rohland, K. Eberle, R. Ströbel, J. Scholta, J. Garche, Electrochim. Acta, 1998, 43, 3841-3846.

[63] B. M. Besancon, V. Hasanov, R. Imbault-Lastapis, R. Benesch, M. Barrio, M. J. Mølnvik, Int. J. Hydrogen Energy, 2009, 34, 2350-2360.

[64] K. Onda, K. Ichihara, M. Nagahama, Y. Minamoto, T. Araki, J. Power Sources, 2007, 164, 1-8.

[65] M. Chatenet, L. Dubau, N. Job, F. Maillard, Catal. Today, 2010, 156, 76-86.

[66] T. A. Zawodzinski, M. Neeman, L. O. Sillerud, S. Gottesfeld, J. Phys. Chem., 1991, 95, 6040-6044.

[67] T. E. Springer, T. A. Zawodzinski, S. Gottesfeld, J. Electrochem. Soc., 1991, 138, 2334

[68] J. T. Hinatsu, M. Mizuhata, H. Takenaka, J. Electrochem. Soc., 1994, $141,1493$.

[69] S. Ge, X. Li, B. Yi, I.-M. Hsing, J. Electrochem. Soc, 2005, 152, A1149.

[70] A. Kusoglu, B. L. Kienitz, A. Z. Weber, J. Electrochem. Soc, 2011, 158, B1504.

[71] P. W. Majsztrik, M. B. Satterfield, A. B. Bocarsly, J. B. Benziger, J. Membrane Sci., 2007, 301, 93-106.

[72] D. M. Bernardi, M. W. Verbrugge, AIChE J., 1991, 37, 1151-1163.

[73] D. Bessarabov, H. Wang, H. Li, N. Zhao, Eds., PEM Electrolysis for Hydrogen Production: Principles and Applications. CRC Press, 2015.

[74] S. S. Kocha, J. D. Yang, J. S. Yi, AIChE J., 2006, 52, 1916-1925.

[75] X. Cheng, J. Zhang, Y. Tang, C. Song, J. Shen, D. Song, J. Zhang, J. Power Sources, 2007, 167, 25-31.

[76] N. T. Truc, S. Ito, K. Fushinobu, Int. J. Heat Mass Transfer, 2018, 127, 447-456.

[77] A. Brunetti, E. Fontananova, A. Donnadio, M. Casciola, M. L. Di Vona, E. Sgreccia, E. Drioli, G. Barbieri, J. Power Sources, 2012, 205, 222-230.

[78] K. D. Baik, B. K. Hong, M. S. Kim, Renew. Energy, 2013, 57, 234-239.

[79] H. K. Lee, H. Y. Choi, K. H. Choi, J. H. Park, T. H. Lee, J. Power Sources, 2004, 132, 92-98.

[80] S. A. Grigoriev, I. G. Shtatniy, P. Millet, V. I. Porembsky, V. N. Fateev, Int. J. Hydrogen Energy, 2011, 36, 4148-4155.

[81] M. Mukaddam, E. Litwiller, I. Pinnau, Macromolecules, 2016, 49 , 280-286

[82] V. A. Sethuraman, S. Khan, J. S. Jur, A. T. Haug, J. W. Weidner, Electrochim. Acta, 2009, 54, 6850-6860. 
[83] S. Suzuki, H. Muroyama, T. Matsui, K. Eguchi, J. Power Sources, 2012, 208, 257-262.
[84] Y. He, E. L. Cussler, J. Membrane Sci., 1992, 68, 43-52.

[85] F. Barbir, H. Görgün, J. Appl. Electrochem., 2007, 37, 359-365.

\title{
电化学氢压缩和纯化与竞争技术的对比: I. 优缺点
}

\author{
Maha Rhandi, Marine Trégaro, Florence Druart, Jonathan Deseure, Marian Chatenet * \\ 格勒诺布尔阿尔卑斯大学, 勃朗峰大学, CNRS, Grenoble-INP, LEPMI, 38000格勒诺布尔, 法国
}

\begin{abstract}
摘要: 毫无疑问, 氢将在我们未来的能量组合中发挥重要作用, 因为它可以储存可再生电(电-氢)并在燃料电池中可逆地转 化为电能, 更不用说它在(石油)化学工业中的广泛应用了. 然而, 在这些应用中需要纯氢, 而如今的制氢仍主要基于化石燃 料, 因而不能被视为纯氢. 因此, 大规模的氢气净化是必须的. 此外, 氢是最轻的气体, 它的体积能量含量远远低于它的竞 争燃料, 除非它在高压下被压缩(通常70MPa), 使压缩不可避免. 本文将详细说明目前可用于氢气净化和压缩的方法. 这将 表明在现有的技术中, 也可以实现氢气净化的电化学氢压缩机(EHC)与目前工业规模上使用的经典技术相比具有许多优 势. EHC有其热力学和操作上的优点, 但也易于使用. 然而, 只有达到足够的性能, EHCs的部署才是可行的, 这意味着他们 的基础材料应遵守一些规范. 本文将详述这些规范.
\end{abstract}

关键词: 电化学氢压缩; 氢能; 电化学氢净化; 热力学; 效率

收稿日期: 2019-05-20. 接受日期: 2019-07-15. 出版日期: 2020-05-05.

*通讯联系人. 电子信箱: Marian.Chatenet@grenoble-inp.fr

本文的电子版全文由Elsevier出版社在ScienceDirect上出版(http://www.sciencedirect.com/science/journal/18722067). 